
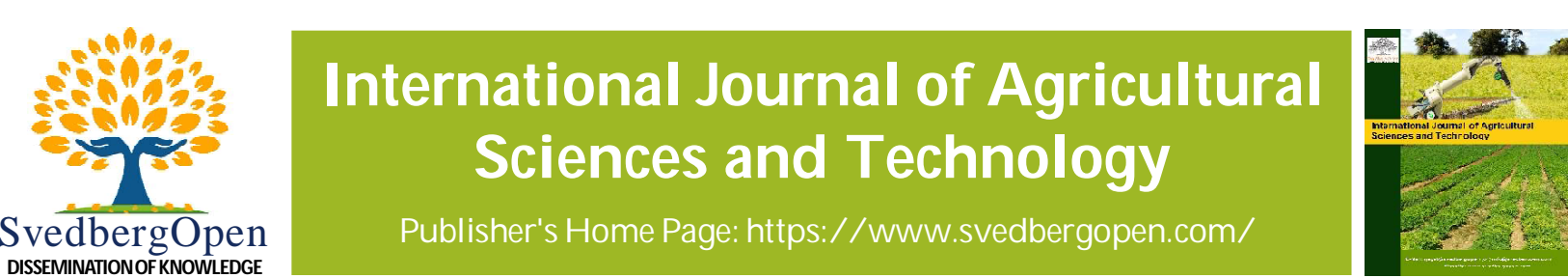

\title{
Incidence of blast disease in oil palm plantation located in Akamkpa local government of Cross River State
}

\author{
Imogie, A.E. ${ }^{1}$, Esiegbuya, O.D. ${ }^{2 *}$, Awelewa, E.A. ${ }^{3}$ and Ojieabu, A. ${ }^{4}$ \\ ${ }^{1}$ Agronomy Division, Nigerian Institute for Oil Palm Research (NIFOR), Benin City. E-mail: imogie@yahoo.com \\ ${ }^{2}$ Plant Pathology Division, Nigerian Institute for Oil Palm Research (NIFOR), Benin City. E-mail: esiegbuya @gmail.com \\ ${ }^{3}$ Research and Development, JB Farms Oil Palm Plantation, Cross River State, Nigeria. \\ ${ }^{4}$ Plant Pathology Division, Nigerian Institute for Oil Palm Research (NIFOR), Benin City, Nigeria.
}

\section{Article Info}

Volume 1, Issue 2, May 2021

Received : 19 November 2020

Accepted : 15 February 2021

Published : 05 May 2021

doi: 10.51483/IJAGST.1.2.2021.33-39

\begin{abstract}
The study into the outbreak of the blast disease in the oil palm plantation in Akamkpa local government of Cross River state was carried out with the aim of identifying the possible sources of contamination of the oil palm seedlings and also the physicochemical parameters of the soil samples. Fungi associated with the blast disease were isolated using the direct plating and bait methods while the physicochemical parameters of the soil were determined using standard methods. The symptoms of the blast disease in the palms begins with rotting of the tips of the roots and then further spreads into the media zone of the cortex resulting in the eventual death of the palm. Fungi isolated from different portion of the affected seedlings, water and soil samples include Pythium, Phytothora, Macrophomina, Aspergillus and Penicillium spp. The results of the soil physical properties of the soil samples showed the particle size analyses of the soils samples to range from $835 \mathrm{gkg} 1$ to $840 \mathrm{gkg} 1$ respectively. The soil texture was sandy loam with an acidic $\mathrm{pH}$ ranging from 5.3 to 5.8. The contents of organic matter ranged from $6.10 \mathrm{~g} \mathrm{~kg}^{-1}$ to $14.25 \mathrm{~g} \mathrm{~kg}^{-1}$, total nitrogen $1.58 \mathrm{~g} \mathrm{~kg}^{-1}$ to $2.25 \mathrm{~g} \mathrm{~kg}^{-1}$, available phosphorus $5.08 \mathrm{mg} \mathrm{kg}^{-1}$ to $6.10 \mathrm{mg} \mathrm{kg}^{-1}$ and potassium $1.16 \mathrm{cmol} \mathrm{kg}^{-1}$ to $2.18 \mathrm{cmol} \mathrm{kg}^{-1}$. The result of this study has indicated that the source of water used for the watering of the oil palm nursery serve as the possible source of introduction of pathogenic pathogens to the oil palm seedlings.

Keywords: Blast disease, Oil palm, Contamination, Seedlings Physicochemical parameters, Soil samples

(C) 2021 International Journal of Agricultural Sciences and Technology. This is an open access article

under the CC BY license (https://creativecommons.org/licenses/by/4.0/), which permits unrestricted

use, distribution, and reproduction in any medium, provided you give appropriate credit to the original author(s) and the source, provide a link to the Creative Commons license, and indicate if changes were made.
\end{abstract}

\section{Introduction}

Blast disease is widespread in Africa (Renard, 1976). This disease can sometimes pose a serious challenge in the polybag system for raising oil palm seedlings. The blast disease of the oil palm was first reported and described in 1944, very little was known about its causal organisms. Prior to this time, some investigators thought that the disease was cause by nematodes such as Aphelenchus avenae Bastian, Cephalobüs, Zeldia, Ditylenchus and Acrobeloides spp. (Robertson, 1959a). The disease was later reported in Malaysia when the polybag system for raising oil palm seedlings was introduced (Turner 1965a). Prior to this time, the ground bed nurseries had been the standard method of raising oil palm seedlings for field planting in Nigeria (Aderungboye, 1976).

\footnotetext{
* Corresponding author: Esiegbuya, O.D. Plant Pathology Division, Nigerian Institute for Oil Palm Research (NIFOR), Benin City. E-mail: esiegbuya@gmail.com,imogie@yahoo.com
} 
According to Turner (1976), the outbreak of the disease is between mid-October and mid-December occurring in palms seedlings with about 5-9 leaves. The disease is characterized by browning of the lower set of leaves which later spreads to the younger ones while in the inner tissues of the young palms brown rot occurs leading to death. In older palms, the cortex of is affected (Aderungboye, 1972). Microorganisms associated with the blast disease include Pythium splendens isolated from the tips of the decaying palms while Rhizoctonia lamelifera was isolated from the cortex. Fusarium solani and F. oxysporum was also isolated from the root tissues of affected palms (Aderungboye, 1972). According Rajagopalan and Aderungboye (1968), the symptom of the blast disease can be induced by soaking the roots of healthy young seedlings in an inoculum made of mixture of Phythium splendens and Rhizoctonia lamelifera. The authors found that $P$. splendens induce the wilting symptoms while R. lamelifera destroying the cortical tissues. This technique however gave a different result in Ivory Coast locations (IRHO, 1972). Bachy (1958) also noted that the susceptibility of the young palms to the blast disease varied with age of the young palms. Due to these contradicting reports of the etiology of the blast disease, Renard (1976) concluded that the origin of the blast disease still remains obscure. This was because the disease seems closely related to specific ecological conditions. Ecological studies on blast pathogens by Aderungboye (1976) showed that the infective propagules of the pathogens were widely distributed in soil and their recovery from the soil is determined by the root baiting technique. Cultural practices and soil environmental factors was also found to play different roles. In the work of Aderungboye (1976) P. splendens was found to be widely distributed in both forest and cultivated, arable soils in Nigeria. Robertson (1959a; 1959b) indicated that the disease can easily be induced by Phythium spp. when the moisture content is below $10 \%$.

Management strategies towards the control of blast disease include shading with good irrigation system for the seedlings during the first months of nursery and especially during dry season so as to provide an unfavorable condition for the pathogen (Renard, 1976). Rajagopalan and Aderungboye $(1968 ; 1969)$ shows that with Nigeria climatic conditions, blast affect seedlings transplanted between June and August when compared to those transplanted between April and May. This is because the seedlings will be well established before the dry season commences. It is therefore recommended that transplanting be done between April and May. Soil types with varying proportions of clay, sand and organic matter with $\mathrm{pH}$ ranging from 4.5-9 have also been suspected to reduce the incidence of blast disease.

The blast disease of the oil palm has been under control and outbreak has not been reported for a long period of time not until recently in late 2019 where a suspected outbreak of the disease was reported in an oil palm plantation, located Akamkpa Local Government Area of southern Cross River state. The major objective of this study was to identify the disease, determine the possible sources of contamination or the host of the causal agent of the blast disease on the oil palm seedlings.

\section{Materials and methods}

\subsection{Location of the study}

The study was conducted at an oil palm plantation, located Akamkpa Local Government Area of southern Cross River state. The area is within the humid tropical climate characterized by distinct wet and dry seasons. The mean annual rainfall ranges between $1500-3500 \mathrm{~mm}$, relative humidity $80-90 \%$ and mean annual temperature value between 25.4-27.5 ${ }^{\circ} \mathrm{C}$. These data were adapted from Calabar weather station of the Nigerian Meteorological Agency being situated within $100 \mathrm{~km}$ range of the synoptic station. The location of the study is on a basement complex geological material of which $40 \%$ encapsulates the entire southern Cross River state.

\subsection{Vegetation and land use}

The area is covered with secondary forest regrowth with few annual crops identified consist of Zea mays, Manihot spp, Dioscorea spp, and perennial crops such as Carica papaya, Elaeis guineensis, Hevea brasiliensisand Irvingia gabonensis. Dominant trees, climbers, and shrubs such as Daniella oliveri, Ficus spp, Khaya senegalensis, Laxifora spp, Combretum spp,Alcohornea spp, Andropogon spp, and Digitaria spp, are scattered almost evenly while African bamboo trees grow wildly near the streams and lowland areas.

\subsection{Soil sampling and preparation}

The soils samples were collected according to the guidelines of USDA-NRCS (Soil Survey Staff, 2002) as modified by Ibanga (2003) and Esu (2010). Samples were collected for soil physical and chemical determinations. Samples were then taken from nursery sites, top soil collection sites and the field. The collected samples were bagged, labeled and transported to the laboratory for analysis. Prior to analysis, the samples were air dried, gently crushed and sieved through $2 \mathrm{~mm}$ sieve.

Symptomatology: This was done with the aid of a digital camera and the symptoms described. 


\subsection{Determination of the most occurring Ganoderma spp.}

This was done by modifying the methods described by Tarr (1972).

$$
\text { Disease incidence }(I)=\frac{\text { No. of infected palms }}{\text { Total no. palms examined }} \times 100
$$

\subsection{Isolation of fungi from infected roots and soils}

Isolation of Phythium splendens and Rhizoctonia lamelifera from the affected roots and soil samples was done according to the methods described by Aderungboye (1972). This was done by washing the roots of oil palm seedlings in running tap water to remove soil particles and other debris. The roots were then cut into smaller bits of about $0.5 \mathrm{~cm}-\mathrm{long}$. The bits were further rinsed in three changes of $1 \%$ solution of chloramphenicol solution to inhibit bacterial growth, surfacedried with sterile filter paper and plated on common laboratory agar media such as potato-dextrose agar, com-meal agar, Czapek-dox agar and malt-extract agar. The plates were incubated at $24-27^{\circ} \mathrm{C}$. Fungal colonies growing from the root Segments 1-3 days after plating were subcultured on fresh plates of potato-dextrose agar for identification.

The baiting method also described by Aderungboye (1972) was used for the isolation of Pythium spp. from infected roots. Root segments which were obtained, as already described, were rinsed in five changes of $1 \%$ solution of chloramphenicol. They were surface-dried with sterile filter paper and plated ( 5 per plate) on cassava-dextrose agar with the longitudinal section on the agar medium. The plates were incubated at $24-27^{\circ} \mathrm{C}$ and fungal colonies growing from the root Segments after 18-24 hours of incubation were subcultured on fresh plates of cassava-dextrose agar for identification. Colonies of Pythium sp. were identified by reference to the descriptions given by Waterhouse $(1967 ; 1968)$

\subsection{Laboratory analysis}

The particle size distribution was determined using the Bouyoucos hydrometer method (Gee and Bauder, 1986) and the percent sizes later used to ascertain the soil textural class with the aid of the soil textural triangle provided by USDA. Soil $\mathrm{pH}$ was determined potentiometrically in the soil-water ratio of 1:1 (Udo et al., 2009) and organic carbon was determined by the Walkley and Black wet oxidation method. Exchangeable cations were extracted using 1NNH4OAc (pH 7.0) and, exchangeable $\mathrm{Ca}^{2+\mathrm{ni}}$ and $\mathrm{Mg}^{2+\mathrm{ni}}$ determined by atomic absorption spectrophotometry (Thomas, 1996) while $\mathrm{Na}^{+\mathrm{ni}}$ and $\mathrm{K}^{+\mathrm{ni}}$ were determined by flame photometry. Effective cation exchangeable capacity was determined by summing up the exchangeable bases and exchangeable $\mathrm{Al}^{3+\mathrm{ni}}$ as outlined by Udo et al. (2009). Base saturation was obtained by expressing the sum of exchangeable cations as a percentage of the cations exchange capacity (IITA, 2000) using the formula;

B.S $=[$ TEB/ECEC $]$ X $100(\%)$.

\section{Results}

\section{a. Disease incidence and symptomatology of the blast disease in the nursery}

The total seedlings as at the nursery was 173,976 out of which 9,368 representing $5.3 \%$ were affected by suspected disease. The symptoms of the blast disease observed in the palms begins with rotting of the roots and spreads to other roots (Plate 1) and into the media zone of the cortex (paerenchyma) leaving the central cylinder and the external cortex intact (Plate 2). This leads to death of the spear rot (Plate 3) and eventual death of the palm (Plate 4). The percentage occurrence of this disease in the nursery was about $5.3 \%$ representing 9,368 of the total seedlings.
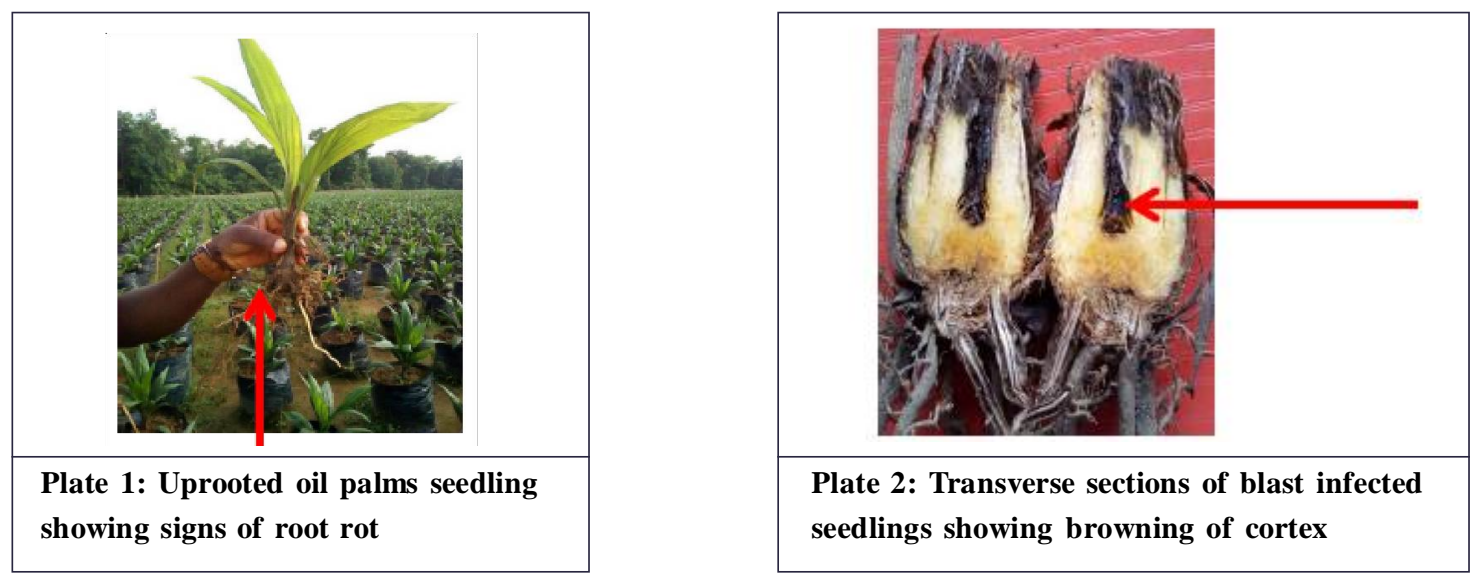

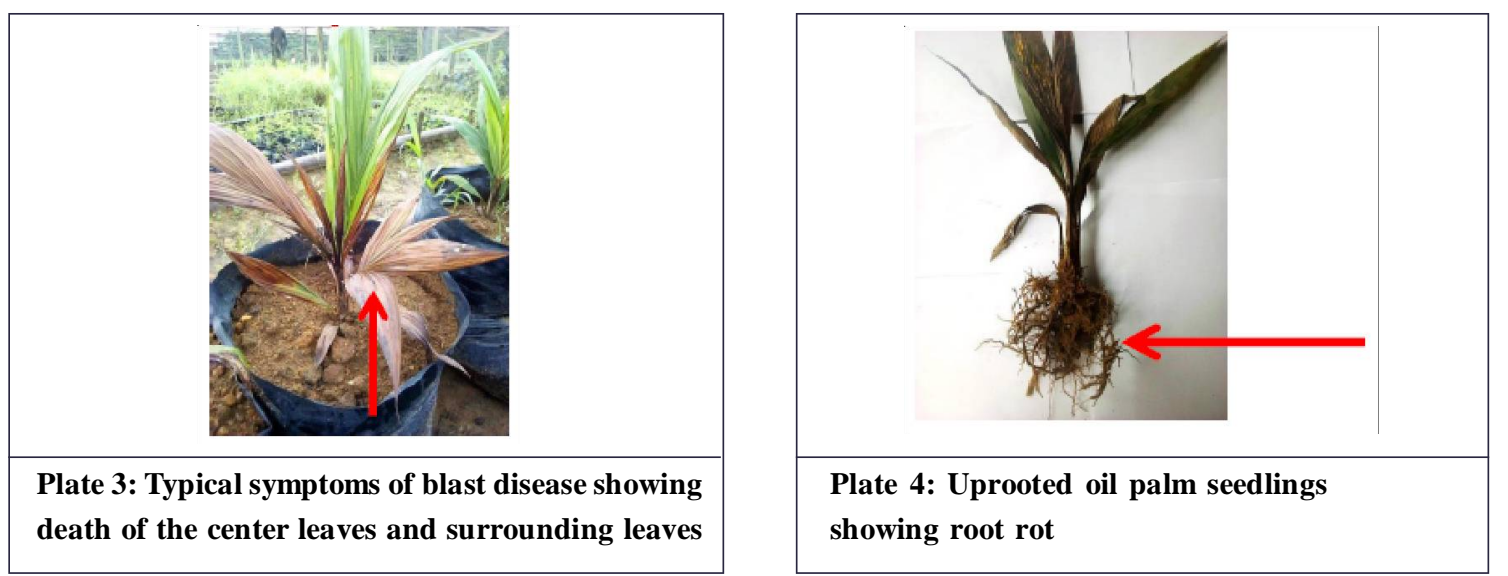

\section{b. Fungi associated with the blast disease}

The result of the microbial analyses of the internal tissues and roots of the infected palm seedlings revealed the presence of Macrophomina sp. and species of Pythium and Phytothora. While fungi isolated from the different soil samples includes Pythium, Phytothora, Macrophomina, Aspergillus and Penicilium spp. Pythium and Phytothora spp. were only isolated from the water samples.

\subsection{Climatic condition for oil palm cultivation}

The climate parameters (annual rainfall, mean annual temperature, and relative humidity) were sufficient for oil palm production. The mean annual rainfall was $2000 \mathrm{~mm}$, while that of the temperature and relative humidity in this region are greater than $25^{\circ} \mathrm{C}$ and $80 \%$ respectively.

\subsection{Physical and chemical properties of the soil}

The results of the soil physical properties of the soil samples (Table 1) showed the particle size analyses of the soils samples to range from $835 \mathrm{gkg} 1$ to $840 \mathrm{gkg} 1$ respectively. The soil texture was sandy loam with an acidic $\mathrm{pH}$ ranging from 5.3 to 5.8. The contents of organic matter ranged from $6.10 \mathrm{~g} \mathrm{~kg}^{-1}$ to $14.25 \mathrm{~g} \mathrm{~kg}^{-1}$, total nitrogen $1.58 \mathrm{~g} \mathrm{~kg}^{-1}$ to $2.25 \mathrm{~g} \mathrm{~kg}^{-1}$, available phosphorus $5.08 \mathrm{mg} \mathrm{kg}^{-1}$ to $6.10 \mathrm{mg} \mathrm{kg}^{-1}$ and potassium $1.16 \mathrm{cmol} \mathrm{kg}^{-1}$ to $2.18 \mathrm{cmol} \mathrm{kg}^{-1}$. The overall physical and chemical properties of the soil samples from the farm ranges from moderate to high fertility.

\begin{tabular}{|c|c|c|c|c|c|}
\hline Samples & Pythium sp. & Phytothora sp. & Macrophomina sp. & Aspergillus sp. & Penicillium sp \\
\hline \multicolumn{6}{|c|}{ Affected oil palm seedlings } \\
\hline a. Internal tissues & + & + & + & - & - \\
\hline b. Rotted roots & + & + & + & + & + \\
\hline \multicolumn{6}{|c|}{ Healthy oil palm seedlings } \\
\hline a. Internal tissues & - & - & - & + & + \\
\hline b. Rotted roots & - & - & - & + & + \\
\hline \multicolumn{6}{|l|}{ Soil samples } \\
\hline a. Nursery bed & + & + & + & + & + \\
\hline b. Dumping site & + & + & + & + & + \\
\hline c. Top soil & + & + & + & + & + \\
\hline Water source (Stream) & + & + & - & - & - \\
\hline
\end{tabular}




\begin{tabular}{|c|c|c|c|c|c|c|c|c|}
\hline \multicolumn{9}{|c|}{ Parameters } \\
\hline Sites & $\begin{array}{c}\text { Sand } \\
\left(\mathrm{g} \mathrm{kg}^{-1}\right)\end{array}$ & $\begin{array}{c}\text { Slit } \\
\left(\mathrm{g} \mathrm{kg}^{-1}\right)\end{array}$ & $\begin{array}{l}\text { Clay } \\
\left(\mathrm{g} \mathrm{kg}^{-1}\right)\end{array}$ & $\begin{array}{c}\text { Slit/Clay } \\
\text { ration }\end{array}$ & $\begin{array}{c}\text { Bulk } \\
\text { density }\end{array}$ & $\begin{array}{l}\text { Particle } \\
\text { density }\end{array}$ & Porosity & $\begin{array}{c}\text { Textural } \\
\text { class }\end{array}$ \\
\hline Nursery soil & 835 & 43 & 122 & 0.35 & 1.33 & 2.12 & 373 & SL \\
\hline Dumping site & 840 & 47 & 113 & 0.42 & 1.37 & 2.17 & 369 & SL \\
\hline Field & 834 & 44 & 112 & 0.36 & 1.33 & 2.12 & 376 & SL \\
\hline Top soil & 844 & 41 & 115 & 0.35 & 1.33 & 2.12 & 376 & SL \\
\hline Mean & 38.25 & 43.75 & 115.5 & 0.37 & 1.34 & 2.14 & 370 & \\
\hline
\end{tabular}

Table 3: Chemical properties of soil in the oil palm plantation

\begin{tabular}{|l|c|c|c|c|c|c|c|c|c|c|c|c|}
\hline \multicolumn{10}{|c|}{ Parameters } \\
\hline Sites & $\mathbf{p H}$ & $\begin{array}{c}\text { Organic } \mathbf{C} \\
\left(\mathbf{g k g}^{-1}\right)\end{array}$ & $\begin{array}{c}\text { Total N } \\
\left(\mathbf{g k g}^{-1}\right)\end{array}$ & $\begin{array}{c}\text { P (Bray) } \\
\left(\mathbf{m g k g}^{-1}\right)\end{array}$ & $\mathbf{K}$ & $\mathbf{C a}$. & Mg. & Na. & CEC & ECEC & EC & EA \\
\hline Nursery soil & 5.8 & 14.25 & 1.91 & 5.84 & 2.15 & 3.75 & 0.58 & 0.95 & 5.52 & 5.43 & 10.34 & 2.51 \\
\hline Dumping site & 5.3 & 10.15 & 2.28 & 6.10 & 1.16 & 3.41 & 0.53 & 1.91 & 5.35 & 5.01 & 10.11 & 3.47 \\
\hline Field & 5.5 & 6.10 & 1.58 & 5.38 & 2.18 & 3.85 & 0.61 & 1.45 & 6.10 & 6.39 & 12.31 & 3.51 \\
\hline Top soil & 5.4 & 14.21 & 1.58 & 5.08 & 2.18 & 3.75 & 0.65 & 1.05 & 5.38 & 5.61 & 10.14 & 3.63 \\
\hline Mean & 5.5 & 11.17 & 1.84 & 5.6 & 1.91 & 3.69 & 0.59 & 1.34 & 5.54 & 5.61 & 10.73 & 3.28 \\
\hline
\end{tabular}

\section{Discussion}

The oil palm (Elaeis guineensis Jacq.) is native to West and Central Africa, occurring as wild and semi-wild groves within the forest zone from Guinea to Angola (Hartley, 1988). It is endemic to the humid tropical rainforest regions of South Eastern Nigeria and South Western Cameroon (Ataga and Van der Vossen, 2007). These groves constitute the genetic diversity existing within the species. A high concentration of wild and semi-wild groves estimated at about 2.1 million hectares occurs in Nigeria, accounting for about 55\% of the total natural grove populations (Omoti, 2009).

The most serious threat to the successful establishment of oil palm nurseries is a root disease commonly called "blast". It is essentially a nursery disease and causes the death of seedlings, seedling losses due to the blast disease in Nigeria are about 8-10\% annually and in some years, losses may be as high as 20\% (Robertson, 1959a). Heavy losses of valuable nursery seedlings result in considerable financial losses and inevitable delay in field planting programs.

The symptom of the blast disease observed in this study was similar to those described by Aderungboye, (1976). However, the incident rate of the blast disease recorded was quite low. This was attributed to quick response of the farm management.

Pythium splendens, $R$. lamelifera, F. solani and F. oxysporum had previously been isolated and identified to be associated with the blast disease (Aderungboye, 1976). However, in this study, Pythium, Phytothora spp. and Macrophomina phaseolina was isolated from affected plants and also from the water source. The isolation of Pythium and Phytothora spp. from the water source indicates that the source of water use in watering might be a probable source of introduction of the pathogens to the oil palm seedlings. Pythium and Phytothora spp. have the potential of attacking plants at different stages of growth, thereby killing them by destroying their roots. Pythium and Phytothora spp. are obligate parasites belonging to the group Oomycota, order Peronosporales they are found in sea, fresh water, and 
terrestrial habitat either as parasites or saprotrophs thereby colonizing plants tissues hence their isolation from the water and soil samples.

Macrophomina phaseolina on the other hand is also a soil borne pathogen which has the potential to induces diseases on a range of crops, ranging from seedling blight, root and stem rot, wilt, and pre- to post-emergent damping off, which can result in decreased stem height, girth, root and head weight, or death, of affected plants (Raut, 1983). Its isolation from this study indicates that its plays a role in the rotting of the roots of the oil palm seedling and also in the decreased height of some of the oil palm seedlings noticed in the nursery. Macrophomina phaseolina is also a soil borne pathogen which has the potential to induces diseases on a range of crops, ranging from seedling blight, root and stem rot, wilt, and pre- to post-emergent damping off, which can result in decreased stem height, girth, root and head or death, of affected plants (Raut, 1983).

Soil properties consist of both micro- and macro- elements. The direct effect of micro- and macro- elements includes production of defense-related compounds, while the indirect effects include soil nitrification, $\mathrm{pH}$ and chemical transformation of micronutrients (Elmer, 2015). Soil nutrient sufficiency has been reported to provide a general form of disease resistance by maintaining a high level of inhibitory compounds in tissue or a quick response to invasion by a pathogen (Huber and Graham, 1999). Studies on the type of soil supporting blast disease are not readily available on literatures however, the results from this study showed that the type of soil in the farm is slightly acidic sandy loamy soil. Previous studies by Robertson (1959b) showed that reducing soil $\mathrm{pH}$ to about 8.5 can reduce the incidence of blast disease. In this study, the overall soil fertility was moderate probably indicating the reason for the low incidence of the blast disease.

\section{Conclusion}

The result of this study has indicated that the source of water used for the watering of the oil palm nursery also serve as a source of the introduction of pathogenic pathogens to the oil palms. For effective management of the blast disease, treatment of water use for nursery palms is highly recommended incorporation with other methods reported in literatures.

\section{References}

Aderungboye, F.O. (I 972). Studies on the blast disease of seedlings of the oil palm (Elaeis guineensis Jacq.), Ph.D. Thesis, University of Ibadan, Nigeria, $281 \mathrm{pp}$.

Ataga, C.D. and van der Vossen, H.A.M. (2007). Elaeis guineensisJacq. In: van der Vossen, H.A.M. \& Mkamilo, G.S. (Editors). Vegetable oils / Oléagineux. [CD-Rom]. PROTA, Wageningen, Netherlands. PROTA 14.

Bachy, A. (1958). Le “bläst” des pepinieres de palmier a huile . Oleagineux, 13: 633-660.

Elmer, W.H. (2015). Using mineral nutrition to suppress plant disease. www.ct.gov/caes

Esu, I.E. (2010). Soil characterization, classification and survey. Heinneman Educational Books Publishers, Nigeria. $232 \mathrm{pp}$

Gee, G.W. and Bauder, J.W. (1986). Particle size analysis. In Klute, A. (ed) Methods of soil analysis, part 1. Agronomy, Vol. 9. American Society of Agronomy Madison, W1 383-411pp.

Hartley, C. (1988). The Oil Palm. 3rd Edition, Editorial Longman, London, 958.

Huber, D.M. and Graham, R.D. (1999). The role of nutrition in crop resistance and tolerance to diseases. In: Rengel Z (ed) Mineral nutrition of crops: fundamental mechanisms and implications. New York: Food Products Press. pp. 16906.

IITA (2000). Selected methods for soil and plant analysis. International Institute of Tropical Agriculture manual series No.1 Review editions. IITA Ibadan, Nigeria 70pp.

IRHO, (1972). Rapport annuel, Institute Research Huiles Oleagineux. p. 68

Rajagopalan, K. and Aderungboye, F.O. (1969). Plant pathology division. Annual Report. Nigerian Institute for Oil Palm Research. 5, 85-91.

Raut J.G. (1983). Transmission of seed borne Macrophomina phaseolina in seed. Science and Technology. 11, $807-817$.

Renard J.L(1976). Diseases in Africa and South America. In Development in Crop Science 1 Oil Palm Research, Corley, 
R.H.V., Hardon, J.J. and Wood, B.J. Elsevier Scientific Publishing Company.

Robertson, J. S. (1959a). Blast disease of the oil palm: its cause, incidence and control. Nigeria. Journal of West Africa Institute of Oil Palm Research. 2, 310-330.

Robertson, J.S. (1959b). Co-infection by a species of Pythium and Rhizoctonia lamelli/era small in blast disease of oil palm seedlings. Transaction of British Mycological Society. 42, 401-405.

Soil Survey Staff (2002). Field book for describing and sampling soils. Version 2.0 National Soil Survey Center, Natural Resources Conservation Service, USDA Lincoln Nebraska.

Thomas, G.W. (1996). Exchangeable Cations, In: Methods of soil analysis- Part 2. Chemical and Microbiological. 9(2), 159-164.

Cite this article as: Imogie, A.E., Esiegbuya, O.D., Awelewa, E.A. and Ojieabu, A. (2021). Incidence of blast disease in oil palm plantation located in Akamkpa local government of Cross River State. International Journal of Agricultural Sciences and Technology. 1(2), 33-39. doi: 10.51483/IJAGST.1.2.2021.33-39. 